\title{
Protecting Australia's children: A cross-jurisdictional review of domestic violence protection order legislation
}

\begin{abstract}
Increasingly, domestic violence is being treated as a child protection issue, and children affected by domestic violence are recognised as experiencing a form of child abuse. Domestic violence protection order legislation - as a key legal response to domestic violence-may offer an important legal option for the protection of children affected by domestic violence. In this paper, we consider the research that establishes domestic violence as a form of child abuse, and review the provisions of state and territory domestic violence protection order legislation to assess whether they demonstrate an adequate focus on the protection of children.
\end{abstract}

\section{Key words}

Domestic violence, child abuse, child protection, protection order, children affected by domestic violence 


\section{Introduction}

In the past, domestic violence (which is also referred to as family violence or intimate partner violence) and child abuse were frequently treated as separate issues, with "a sharp demarcation line being drawn between them" (Parkinson \& Humphreys, 1998:147; Matthews, 1999:50-51). Indeed, child protection systems and domestic violence programs have not traditionally worked collaboratively. Findlater and Kelly (1999:87) describe the history of the relationship between child protection and domestic violence services as "difficult", with misunderstandings in ideals and purpose, and "mistrust on both sides". As recently as 2009, Douglas and Walsh's (2009:53) study found that some child protection workers continue to "accept dominant myths about domestic violence, for example, that domestic violence is just a relationship issue". They also found evidence of child protection workers constructing "women as the one with the responsibility to care for children, and then blaming women for the domestic violence in the home and the consequent failure to protect their children" (Douglas \& Walsh, 2009:55).

Notwithstanding these difficulties, there is growing recognition, both within and outside Australia, that domestic violence is itself a child protection issue (Parkinson and Humphreys, 1998:148; Matthews, 1999:50-51; The National Council to Reduce Violence against Women and their Children, 2009b; Australian and New South Wales Law Reform Commissions (ANSWLRC), 2010; Douglas \& Walsh, 2009, 2010). This analytical shift owes much to a growing body of research demonstrating: first, the high co-occurrence of domestic violence and child abuse; and second, the abusive nature and negative impact on children of living with domestic violence (e.g. see Fantuzzo \& Mohr, 1999; Osofsky, 1999; Tomison, 2000; Laing, 2003; Holt, et al., 2008; Richards, 2011).

However, this recognition of the intersection between domestic violence and negative consequences for children appears to have resulted in enlarging the child protection "net" to 
include children affected by domestic violence. Consequently, there is some evidence to suggest that "simply 'grafting' domestic violence onto the existing child protection system" is overwhelming "the statutory child protection system in a number of Australian jurisdictions" (Humphreys, 2007:1-2). A broader approach needs to be taken, making "greater use of other services [and mechanisms] that support the safety and well-being of children and their families in order to reduce the number of children affected by domestic violence who are referred to statutory child protection" (Humphreys, 2007:1-2).

One potential legal measure that may offer an important mechanism for the protection and safety of children affected by domestic violence in Australia are domestic violence protection order laws ${ }^{1}$. Domestic violence protection order legislation is a critical protective tool, not only for adult victims of domestic violence, but also for their children. The efficacy of the legislation in achieving safety for children affected by domestic violence therefore warrants scrutiny.

In this paper, we provide the results of a comparative review of the protection order legislation in each state and territory of Australia as it applies to children affected by domestic violence. Specifically, we analyse the status and position of children in relation to the legislative guiding principles and objectives, the protective scope of the legislation (as found, e.g., in the definitions of violence and applicable relationships), procedural mechanisms, and matters specified to be considered by the court when making a protection order. However, it is important to clarify our meaning of domestic violence, as this is an

\footnotetext{
${ }^{1}$ Domestic violence protection orders are currently available through the following state and territory legislation: the Crimes (Domestic and Personal Violence) Act 2007 (New South Wales), Domestic and Family Violence Act 2007 (Northern Territory), Domestic and Family Violence Protection Act 2012 (Queensland), Domestic Violence and Protection Orders Act 2008 (Australian Capital Territory), Family Violence Act 2004 (Tasmania). Family Violence Protection Act 2008 (Victoria), Intervention Orders (Prevention of Abuse) Act 2009 (South Australia), Restraining Orders Act 1997 (Western Australia).
} 
"area in which there are multiple perspectives and understandings of different terms and language" (Humphreys, 2007:2).

\section{Definitions of domestic violence and a child in need of protection}

Given our focus on legislation, we adopt legislative definitions of domestic violence and child protection. However, these definitions are consistent with the definitions used in larger policy debates around domestic violence and child protection. For instance, the definition of 'domestic violence' supported by the Australian Domestic and Family Violence Clearinghouse (and that adopted in 1997 by the Commonwealth Partnerships against Domestic Violence (PADV) program) is:

Domestic violence is an abuse of power perpetrated mainly (but not only) by men against women both in relationships and after separation. It occurs when one partner attempts physically or psychologically to dominate and control the other. Domestic violence takes a number of forms. The most commonly acknowledged forms are physical and sexual violence, threats and intimidation, emotional and social abuse and economic deprivation. ... For many Indigenous people the term family violence is preferred as it encompasses all forms of violence in intimate, family and other relationships of mutual obligation and support (PADV, 1997, citied in ANSWLRC, 2010:188).

The recognition of a range of relationships, types of harm and nature of domestic violence is reflected in most legislative definitions of domestic violence in Australia (Jeffries, Bond \& Field, 2013).

Finally, for our purposes, and similar to other commentators, "children affected by domestic violence' encompasses "children witnessing domestic violence", "children exposed to domestic violence", "children directly abused in the context of domestic violence", "children living with domestic violence", and "children drawn into domestic violence" (Humphreys, 2007:2). 


\section{The nexus between children's exposure to domestic violence and child abuse}

Over the past 30 years, studies have attempted to estimate the number or proportion of children exposed to domestic violence. In the United States, research extrapolating from a nationally representative sample estimated that approximately 15.5 million American children live in families in which domestic violence had occurred at least once in the previous year (McDonald et al., 2006). Results from the Australian Personal Safety Survey showed that 61 percent $(n=822,500)$ of persons who experienced domestic violence by a previous partner (since the age of 15 years) reported having children in their care at some stage during the relationship, and 36 percent $(n=489,400)$ stated these children had witnessed the violence (Australian Bureau of Statistics, 2006:11). Similarly, the Australian component of the International Violence against Women Survey found that "over a third of women who experienced domestic violence $(n=1730)$ reported that their children had witnessed a violent incident (n=616)" (Mouzos \& Makkai, 2004:90).

Exposure of children to domestic violence encompasses more than just witnessing violent events. Children may also: hear the violence; see its effects (e.g., blood, injuries, damaged property); be used as a tool in the abuse (e.g., being forced to spy on a parent by the abusive parent; used to send threatening messages); be blamed for the violence; be used as a hostage by an abusive parent to intimidate/scare their victim; as well as defend a parent against the violence and/or intervene to stop the violence (Parkinson \& Humphreys, 1998:148; Holt et al., 2008; Richards, 2011:1). It also does necessarily not end with the separation of the perpetrator and victim. Research consistently shows that domestic violence is likely to continue post-separation and may often increase in severity (Laing, 2003; Fleury et al., 2000). As noted by Parkinson and Humphreys (1998:148) domestic violence in families "does not usually occur in a way which is separated from the lives of children"; they are "frequently either present when the violence occurs, or are made aware of the violence in 
other ways". Thus, in addition to witnessing domestic violence, children are also living with the reality of the violence (ANSWLRC, 2010:243).

Studies also show that domestic violence and child abuse frequently co-occur within the same families (Laing, 2003). In the United States, it is estimated that between 30 and 60 per cent of children with mothers in abusive relationships are abused (Laing, 2003:1). Australian studies of child protection cases similarly support the co-occurrence of domestic violence and child abuse. For example, in Victoria, an investigation of actual or suspected child maltreatment cases found that child protection workers reported domestic violence in 31 per cent of cases (Tomison, 2000:5-6). More specifically, domestic violence was reported as present in cases of $38 \%$ child neglect cases, $37 \%$ of physical abuse cases, and $68 \%$ of emotional abuse cases. Although not reaching conventional levels of statistical significance, domestic violence also featured in around 20\% of sexual abuse cases (Tomison, 2000:5-6).

There are significant negative effects for children who live with domestic violence (Fantuzzo \& Mohr, 1999; Jaffe et al., 2003:205; Holt et al., 2008:798). These include, but are not limited to: low-self-esteem, anxiety and other internalised symptoms of distress (e.g. psychosomatic illnesses, fretful sleeping, nightmares, insomnia, eating disorders, repetitive self-harm, depression), poor academic achievement, social withdrawal, poor social competence, low levels of empathy, and in more extreme cases, posttraumatic stress disorder (see Parkinson \& Humphreys, 1998:148; Holt et al., 2008; ANSWLRC, 2010:243-244; Richards, 2011).

Thus, living with domestic violence is itself a form of child abuse because of the negative implications for children's emotional well-being (Holt et al., 2008:799). Indeed the Time for Action Report noted that "the intersection of child protection and family law in terms of the safety and protection of women and their children was raised constantly to the Council” (National Council to Reduce Violence Against Women and Children, 2009b:83). 
The crime of filicide presents as one of the more shocking examples of the nexus between domestic violence and child abuse (Laing, 2003:2; Domestic Violence Resource Centre Victoria, 2012). Here, the perpetrator of violence's relationship with his children is "secondary to his intermediary use of them to abuse their mother" (Holt et al., 2008:800). For instance, a study of filicides by fathers/step-fathers in the United Kingdom found that violence against the mother featured in 71 per cent of cases $(n=26)$ (Cavanagh et al., 2007:738). In Western Australia, Johnson's (2005:36-47) study of fathers ( $n=7)$ who killed their children $(n=15)$ in the context of separation found that a history of domestic violence (including physical, sexual, emotional, social and financial abuse) was a significant factor in all cases. Arguably, the murder of children in this context is not only the ultimate act of child abuse, it is also a demonstrable manifestation of domestic violence (Domestic Violence Resource Centre Victoria, 2012:63).

\section{Domestic violence protection orders as a child protection mechanism}

There are signs of increasing recognition by government of the link between preventing and responding to domestic violence and the protection of children from child abuse (Matthews, 1999:50). In 2009, the Australian Government released the National Framework for Protecting Australia's Children and The National Plan to Reduce Violence against Women and their Children. Both strategies recognised the connection between domestic violence and child abuse, the negative impacts on children of exposure to domestic violence and the crucial need for decisive policy and legislative action (Council of Australian Governments, 2009; The National Council to Reduce Violence against Women and their Children, 2009b). There was also a strong recognition of the role of civil and criminal justice responses in the protection of women and children who are victims of domestic violence (ANSWLRC, 2010; Nancarrow, 2010). 
More recently, the Carmody Report (2013) recommended a new child protection system which would, where possible, divert children away from government child protection systems and intervention. Importantly, the Report (Carmody, 2013: xx) argued for a system that would be "largely focused on engaging with families and keeping children safely at home, rather than mitigating risk at all costs". Although much of this is about early intervention, legal processes available for children at risk provide a further strategy for protecting children at home.

Domestic violence protection orders offer a critical civil legal remedy for the protection of children at risk due to domestic violence. Protection orders have the potential to positively impact the safety and welfare of children by providing non-violent caregivers and in some instances, other concerned parties (such as police, and child protection workers) as well as the children themselves, a means of seeking legally enforceable protection. However, if increasing awareness of the co-occurrence of domestic violence and child abuse is to be acted upon effectively - and if domestic violence protection orders are to offer an effective legal avenue to achieve the protection of children affected by domestic violence- the link between the safety and well-being of children and the safety and well-being of their mothers in contexts of domestic violence needs to be better recognised (Humphreys, 2007:13; Irwin et al., 2003; Radford \& Hester, 2006).

For example, one of the structural problems "at the heart of the statutory child protection response to children affected by domestic violence" is the absence of recognition that where there is a child who is exposed to domestic violence, there is also an adult victim of violence who is, "more often than not, the child's mother" (Humphreys, 2007:7). Thus, the adult victim (usually, but not always, the mother) of domestic violence may not be recognised or supported through child protection mechanisms. For example, Douglas and Walsh's (2009:55) work indicated that some child protection workers continued to blame mothers 
who were victims of violence for failing to protect their children from domestic violence. Their participants indicated that, at least in Queensland, there was "a problem of understanding the dynamic of domestic violence" within the child protection system, with domestic violence sometimes being "seen as more of an interpersonal conflict situation" (Douglas \& Walsh, 2009:53). Consequently, mothers who were not seen as protective "may not receive appropriate support" (Douglas \& Walsh, 2009:55).

However, "when children are affected by domestic violence, their protection is often linked to the protection [and support] of their mother" (Humphreys, 2007:7) Domestic violence protection orders has the potential to provide a legal mechanism that can do just that: that is, to protect and support mothers, but also provide them with an important way of protecting and supporting their children's well-being (Humphreys, 2007:14). This was recognised by the Carmody Inquiry which argued that "priority access should be given to adults whose children are at risk" (Carmody, 2013: xix).

\section{Australian domestic violence protection order legislation and the protection of children}

Systematic reviews of domestic violence protection order legislation and their focus on protecting children affected by domestic violence have not been undertaken in Australia. In 2010, the Australian and NSW Law Reform Commissions (2010: 960-968) provided a brief overview of the relevant Australian legislation in terms of how it related to children. A key aspect of the Commissions' overview was to highlight the extent of jurisdictional variation in the protection order application processes and the subsequent granting of protection to children. In some jurisdictions, applications can be brought by, or on behalf of a child either by parents or guardians, police officers or child protection workers. Depending on the jurisdiction, there may be obligations on police and/or child welfare officers to apply for protection orders on behalf of children under certain circumstances (ANSWLRC, 
2012:960-968). Thus, courts in some Australian states and territories can grant separate orders for children as protected persons in their own right. In jurisdictions where this is not possible, courts may, but are not always obliged to, include a child as a protected person on orders granted for an adult victim.

In other words, based on this brief review, there is evidence of legislative inconsistency across Australian states and territories. This raises questions about inequality of treatment and subsequent protection for children living with domestic violence across jurisdictions because children in different states and territories will have varying chances of being able to obtain an order.

\section{The current study}

Extending the Australian and New South Wales Law Reform Commissions' review, this study assesses the position of children in each Australian jurisdiction's domestic violence protection order legislation, through a quantitative content analysis of Australian domestic violence protection order legislation in each state and territory in force as at June 2013 (see Appendix A for a list of the legislation covered by the study). The statutes ranged in size from 38 sections (or provisions) to 272 sections. This study focuses on the priorities of governments concerning child protection as contained in domestic violence protection order legislation (in line with the approach of DeJong \& Burgess-Proctor, 2006). It does not examine the practical implementation of the legislation. Although the implementation of protective order legislation is vital to the success of the legislative intent, we are interested in identifying the key themes around child protection in the current statutory language, as this language can play an important symbolic role in affirming or legitimating the protective role for children of such legislation. 
Our approach organises the manifest content and language of the statutes into common categories, allowing us to compare across jurisdictions to identify the extent of common approaches, as well as legislative differences. To do this, we coded information from the legislation only, particularly focusing on the provisions that refer to children. We used two coders to improve the reliability of the data. Where there was disagreement, coding rules were revisited and, where necessary, revised. Specifically, we compare the status and position of children in terms of:

- legislative guiding principles and/or objectives

- protective scope (i.e. definitions of violence and applicable relationships)

- procedural mechanisms

- $\quad$ specified matters to be considered by the court.

Further, we assess the identified legislative protections against 'best practice' as set out by the Australian and New South Wales Law Reform Commissions (2010) and the National Plan for the Reduction of Violence against Women and Children (Council of Australian Governments, 2009) for domestic violence protection order legislation.

\section{Legislative guiding principles/objectives}

The Australian and New South Wales Law Reform Commissions (2010: 315) argued that:

the articulation of core common purposes of family violence [domestic violence protection order] legislation across the states and territories is important because it provides that basis from which a common nation-wide interpretative framework might develop as well as aiding in the development of a shared Australian understanding of family violence across jurisdictions.

In relation to children, the Australian and New South Wales Law Reform Commissions (2010: 307, 308) recommended that domestic violence protection order legislation in all jurisdictions should contain provisions that acknowledged the detrimental impact of family 
violence on children and placed the protection of children within a human rights framework (e.g., drawing on the United Nations Convention of the Rights of the Child).

As noted in Table 1, both the New South Wales and Queensland legislation currently make explicit references to the United Nations Convention on the Rights of the Child in their objectives/preambles. The United Nations Convention on the Rights of the Child states that children have the right to protection, and to be safe from harmful influences and abuse. While the other jurisdictions may not explicitly frame the purposes of their protection order legislation within a children's rights framework, all recognise the need for safety and protection of children. Victoria, Queensland and Tasmania also provide legislative recognition of the adverse impacts on children from living with domestic violence (see Table 1 , below).

[Insert Table 1 about here]

The Commissions also recognised the particularly susceptible status of children living with family violence, noting that children "are generally more vulnerable and less capable of judging how to respond to, and escape from, family violence" (ANSWLRC, 2010:365). This distinct vulnerability is recognised in the legislative objectives/preambles of protection order legislation in two jurisdictions: Victoria and New South Wales (see Table 1).

Finally, a potential purpose of family violence legislation is to ensure minimal disruption to the lives of families affected by violence (ANSWLRC, 2010:309). This purpose is only found in the Queensland legislation, which states in section 4(2)(a) that children who fear or experience domestic violence should have disruption to their lives minimised (see Table 1). 


\section{Protective scope (definitions of domestic violence and applicable relationships)}

One way to achieve equal access to protection orders, irrespective of which state or territory a child resides in, is shared legislative understandings about what constitutes domestic violence and the types of relationships that qualify under legislation (ANSWLRC, 2010). Given the detrimental impacts of domestic violence on children, the Commissions argued that legislative "definitions of family violence ... should expressly acknowledge that exposing a child to the effects of family violence ... is in itself a form of family violence" (ANSWLRC, 2010:242). Nonetheless, as noted in Table 2, Victoria and Queensland are currently the only jurisdictions in which exposure of children to domestic violence is defined in this way.

[Insert Table 2 about here]

For a child to gain protection under domestic violence protection order legislation, they need to be in a legislatively defined relationship with the person engaging in the violence. As demonstrated in Table 2, the majority of state and territory legislation is inclusive of children in that relatives fall within definitions of applicable relationships. However, the Tasmanian legislation only includes within its scope spousal and other intimate relationships. In other words, the Tasmanian legislation does not cover other common relationships (such as child-parent/step-parent or other carer type relationships) in which children may be exposed to domestic violence (see Table 2).

\section{Procedural mechanisms}

The need for accessible and responsive justice processes for children is clearly stated in the National Plan to Reduce Violence against Women and their Children (Council of 
Australian Governments 2010: 26, National Outcome 5). Protection maybe enhanced where there are formal administrative processes that make protection order applications easier in cases involving young victims (DeJong \& Burgess-Proctor, 2006:75). At the very least, legislation should enable children to be named as adjuncts on adult orders. However, allowing children to also obtain orders in their 'own right' extends order accessibility and in turn the possibility of protection against further victimisation. As shown in Table 3, all jurisdictions allow either one or both of these options. However in Queensland, somewhat concerningly, young people aged less than 18 years of age cannot be named as an aggrieved (i.e. victim) on a domestic violence protection order unless there is an intimate or informal care relationship with the perpetrator (but parent/child type relationships are not included under the definition of an informal care relationship: see ss.20(2) \& 22(2), Domestic and Family Violence Protection Act 2012 (Qld)).

[Insert Table 3 about here]

The inclusion of provisions that promote protection independent of the child victim, such as legislation that directs police and child safety agencies to apply, are also likely to be important in improving order accessibility as are court directives and obligations to include children without application in orders granted to other victimised family members. As demonstrated in Table 3, obligatory requirements to file order applications for children are uncommon and occur in only two jurisdictions. In New South Wales, police are required to make an application to the court when a domestic violence offence has been committed against a child aged under 16 years (s.49(1)(b) Crimes (Domestic and Personal Violence) Act 2007 (NSW)). In the Northern Territory, a police officer or child protection officer must apply for a court order for the protection of a child if they reasonably believe that domestic 
violence has been committed or is being committed or is likely to be committed, and the child's wellbeing has or is likely to be adversity affected by the violence (s.29(1)(a) Domestic and Family Violence Act 2007 (NT)).

New South Wales is the only jurisdiction in which courts are obligated to include children on orders without application. Here, under s.38(2) of the Crimes (Domestic and Personal Violence) Act 2007 (NSW), if the court makes an order for the protection of a person aged over 18 years, it must include on the order any child with which the adult has a domestic relationship. Less prescriptively, in Queensland, if an adult victim does not request that a child should be named on an order, the court has to consider whether they should be named (s.54, Domestic and Family Violence Protection Act 2012 (Qld)).

Further, an accessible and responsive justice process should provide mechanisms aimed at protecting children as vulnerable witnesses in the court process. Aside from the Australian Capital Territory, all legislation provides mechanisms for protecting child as witnesses during protection order proceedings (see Table 4). The Western Australian and the Northern Territory legislation do not permit children to give oral evidence in the courtroom. In Victoria, oral evidence may be given but protections during this process are obligatory (i.e., screens are set up between the child witness and perpetrator). In South Australia, New South Wales, Queensland and Tasmania, children's oral evidence in the courtroom is permitted, with protections ordered at the discretion of the court. The courts may also order that evidence be given via recorded statement, CCTV, in writing or video link in all jurisdictions, apart from the Australian Capital Territory. Cross examination of child witnesses by perpetrators is not permitted in the majority of jurisdictions. However, there is no legislative directive against this practice in New South Wales, Tasmania or the Australian Capital Territory (see Table 4). 
[Insert Table 4 about here]

\section{Specified matters to be considered by the court}

The matters that courts are legislatively directed to consider when making protection orders can either promote or impede the safety and well-being of child domestic violence victims (Wilcox, 2010:8). Protection order legislation may direct courts to consider matters such as the safety and protection of children, their social needs and future contact arrangements with parental abusers. As reported in Table 5, when considering order applications all Australian protection order legislation requires the court to consider: (1) children's safety/protection; and (2) the social needs of children through legislative directives around hardship or harm minimisation. For example, in Victoria, in making a decision about whether or not to exclude the perpetrator from residential premises, the court must have regard to the desirability of minimising the disruption to any child living with the victim, the importance of maintaining social networks, support, the desirability of continuity and stability childcare and education (s.82(2) Family Violence Protection Act 2008 (Vic)).

[Insert Table 5 about here]

In our federal system of government, family law matters (including parenting decisions) are governed by federal law while protection order legislation is state and territory based. Nonetheless, evidence suggests that there is hesitation on the part of state and territory courts to make protection orders that do, or could potentially, conflict with Federal Family Court orders allowing abusers contact with their children (The National Council to Reduce 
Violence against Women and their Children, 2009a; ANSWLRC, 2010). ${ }^{2}$ Federal legislative provisions have for some time supported a child's on-going relationship with both parents post-separation where it is in their best interest. Protection order legislation that is focused on children's safety should explicitly recognize the priority of protection and best interests of the child over pre-existing parenting orders and/or parenting arrangements, as research shows that periods of contact with children, particularly the handing-over of children for visitation with domestically violent parents, are times of particularly elevated risk (Kaye et al., 2003; Lynch et al., 2000; The National Council to Reduce Violence against Women and their Children, 2009a:213-243).

Queensland and Victorian legislation provides the most substantial child-safety focused directives in regard to parental contact. In these two jurisdictions, child contact with the perpetrator and the likelihood of this jeopardising their safety is to be considered by the court whether or not there is a Family Court order in place. Conditions can be imposed that restrict or prohibit contact between perpetrators and children. Further, in considering preexisting Family Court Orders, child safety is prioritised and courts are directed to use existing powers under section 68R of the Family Law Act 1975 (Cth) to adjust, discharge or suspend these orders in the interest of child safety. At the other end of the child protection spectrum, Tasmania, the Australian Capital and the Northern Territory provide no legislative directives around perpetrator contact with children. New South Wales only requires child safety to be prioritised over pre-existing Family Court orders (see Table 5).

\section{Conclusion}

\footnotetext{
${ }^{2}$ We note that to avoid actual or potential conflict between parenting and protection orders the Family Law Act 1975 (s.68R) does provide state/territory courts with a mechanism to make parental contact orders, vary, suspend or discharge Family Court orders (The National Council to Reduce Violence against Women and their Children 2009a:213-243).
} 
Exposure of children to domestic violence is increasingly being classified as a form of child abuse, thus increasing the likelihood of intervention by child protection agencies. However, there are other legal mechanisms which should be considered, particularly the use of domestic violence protection orders. The current study has explored Australian state and territory domestic violence protection order legislation and its ability to protect children affected by domestic violence. Our analysis has shown that although there are a number of common themes (especially around legislative objectives and applicable relationships), there is considerable variation between the jurisdictions. The extent of the variation raises issues of equity: different jurisdictions offer differing levels of protection to children exposed to domestic violence. In other words, protection depends on the jurisdiction in which the child lives. 


\section{References}

Australian Bureau of Statistics. (2006). Personal Safety Survey. Canberra: Australian Bureau of Statistics.

Australian and New South Wales Law Reform Commissions. (2010). Family Violence - Aa National Legal Response. Canberra: Australian Law Reform Commission.

Carmody, T. (2013). Taking Responsibility: A Roadmap for Queensland Child Protection. Brisbane: State of Queensland.

Cavanagh, K., Dobash, R.E. \& Dobash, R.P. (2007). The murder of children by fathers in the context of child abuse. Child Abuse and Neglect, 31, 731-746.

Council of Australian Governments. (2009). Protecting Children is Everyone's Business: A National Framework for Protecting Australia's Children 2009-2020. Canberra: Commonwealth of Australia.

DeJong C. \& Burgess-Proctor A. (2006). A summary of personal protection order statutes in the United States. Violence Against Women, 12(1), 68-88.

Domestic Violence Resource Centre Victoria. (2012). 'Just Say Goodbye': Parents who Kill Their Children in the Context of Separation. Melbourne: Domestic Violence Resource Centre Victoria.

Douglas, H. \& Walsh, T. (2009). Mothers and the child protection system. International Journal of Law Policy and the Family, 23(2), 211-229.

Fantuzzo, J.W. \& Mohr, W.K. (1999). Prevalence and effects of child exposure to domestic violence. Domestic Violence and Children, 9(3), 21-32.

Findlater, J.E. \& Kelly, S. (1999). Child protective services and domestic violence. Domestic Violence and Children, 9(3), 84-96.

Fluery, R.E., Sullivan, C.M. \& Bybee, D.I. (2000). When ending the relationship does not end the violence. Violence Against Women, 6(12), 1363-1383. 
Holt, S., Buckley, H. \& Whelan, S. (2008). The impact of exposure to domestic violence on children and young people: a review of the literature. Child Abuse and Neglect, 32, 797-810.

Humphreys, C. (2007). Domestic Violence and Child Protection: Challenging Directions for Practice. Sydney: Australian Domestic \& Family Violence Clearinghouse.

Irwin, J., Waugh, F., \& Wilkinson, M. (2003). Domestic violence and child protection. National Child Protection Clearinghouse Newsletter, 11(1), 7-9.

Jaffe, P.G., Crooks, C.V. \& Wolfe, D.A. (2003). Legal and policy responses to children exposed to domestic violence: the need to evaluate intended and unintended consequences. Clinical Child and Family Psychology Review, 6(3), 205-213.

Jeffries, S., Bond, C., Field, R. (2013). Australian Domestic Violence Order Legislation: A Comparative Quantitative Content Analysis of Victim Safety Provisions. Current Issues in Criminal Justice, 25(2), 627-643.

Johnson, C.H. (2005). Come with Daddy: Child Murder-Suicide after Family Breakdown. Perth: University of Western Australia Press.

Kaye, M., Stubbs, J. \& Tolmie, J. (2003). Domestic violence, separation and parenting: negotiating safety using legal processes. Current Issues in Criminal Justice, 15(2), 7394.

Laing, L. (2003). Domestic Violence in the Context of Child Abuse and Neglect. Sydney: Australian Domestic violence Clearinghouse.

Lynch, A., Rathus, Z. and Redell, K. (2000). An Unacceptable Risk: A Report on Child Contact Arrangements Where There is Violence in the Family. Brisbane: Women's Legal Service.

Matthews, M.A. (1999). The impact of federal and state laws on children exposed to domestic violence. The Future of Children, 9(3), 50-66. 
McDonald, R., Jouriles, E.N., Ramisetty-Mikler, S., Caetano, R. \& Green, C.E. (2006). Estimating the number of American children living in partner violent families. Journal of Family Psychology, 20(7), 137-142.

Mouzos, J. \& Makkai, T. (2004). Women's Experiences of Male Violence: Findings from the Australian Component of the International Violence Against Women Survey. Canberra: Australian Institute of Criminology.

Nancarrow H. (2010). Time is of the essence: progress on the national council's plan to reduce violence against women and their children. University of New South Wales Law Journal. 33(3), 836-853.

National Council to Reduce Violence against Women and their Children. (2009a). Domestic Violence Laws in Australia. Canberra: Commonwealth of Australia.

National Council to Reduce Violence against Women and their Children. (2009b) Time for Action: The National Council's Plan for Australia to Reduce Violence against Women and Their Children, 2009-2021. Canberra: Commonwealth of Australia.

Osofsky, J.D. (1999). The impact of violence on children. Domestic Violence and Children, $9(3), 33-49$.

Parkinson, P. \& Humphreys, C. (1998). Children who witness domestic violence - the implications for child protection. Child and Family Law Quarterly, 10, 147-160

Partnerships Against Domestic Violence (PADV). (1997). First Report of the Taskforce 1997-1999. Canberra: Commonwealth of Australia.

Radford, L. \& Hester, M. (2006) Mothering Through Domestic Violence. London: Jessica Kingsley.

Richards, K. (2011). Children's Exposure to Domestic Violence in Australia. Canberra: Australian Institute of Criminology. 
Tomison, A. (2000). Exploring Family Violence: Links between Child Maltreatment and Domestic Violence. Melbourne: Australian Institute of Family Studies.

Wilcox, K. (2010). Recent Innovations in Australian Protection Order Law: A Comparative Discussion. Sydney: Australian Domestic Violence Clearinghouse.

\author{
Legislation/Conventions Cited \\ Family Law Act 1975 (Commonwealth) \\ United Nations Convention on the Rights of the Child
}

\author{
Appendix: Australian domestic violence protection order legislation included in the \\ study \\ Crimes (Domestic and Personal Violence) Act 2007 (New South Wales) \\ Domestic and Family Violence Act 2007 (Northern Territory) \\ Domestic and Family Violence Protection Act 2012 (Queensland) \\ Domestic Violence and Protection Orders Act 2008 (Australian Capital Territory) \\ Family Violence Act 2004 (Tasmania) \\ Family Violence Protection Act 2008 (Victoria) \\ Intervention Orders (Prevention of Abuse) Act 2009 (South Australia) \\ Restraining Orders Act 1997 (Western Australia)
}

URL: http://mc.manuscriptcentral.com/tppl 
Australian Domestic violence Order Legislation - Guiding Principles/Objectives Relating to Children

\begin{tabular}{|c|c|c|c|c|c|}
\hline & $\begin{array}{l}\text { Recognition that Australia is } \\
\text { party to the UN Convention on } \\
\text { the Rights of the Child }\end{array}$ & $\begin{array}{l}\text { Safety/Protection and/or Well- } \\
\text { Being of Children is important }\end{array}$ & $\begin{array}{c}\text { Disruption to Children's Lives } \\
\text { Should be Minimised }\end{array}$ & $\begin{array}{l}\text { Recognition of the Vulnerable } \\
\text { Status of Children Living with } \\
\text { DOMESTIC VIOLENCE }\end{array}$ & $\begin{array}{l}\text { Recognition of the Adverse } \\
\text { Impacts on Children from } \\
\text { Living with DOMESTIC } \\
\text { VIOLENCE }\end{array}$ \\
\hline South Australia & & $\sqrt{ }$ & & & \\
\hline Victoria & & $\sqrt{ }$ & & $\sqrt{ }$ & $\sqrt{ }$ \\
\hline Western Australia & & $\sqrt{ }$ & & & \\
\hline New South Wales & $\sqrt{ }$ & $\sqrt{ }$ & & $\sqrt{ }$ & \\
\hline Queensland & $\sqrt{ }$ & 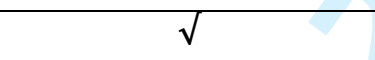 & $\sqrt{ }$ & & $\sqrt{ }$ \\
\hline Tasmania & & $\sqrt{ }$ & 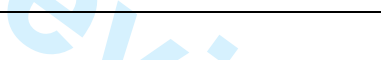 & & $\sqrt{ }$ \\
\hline $\begin{array}{l}\text { Australian Capital } \\
\text { Territory }\end{array}$ & & $\sqrt{ }$ & 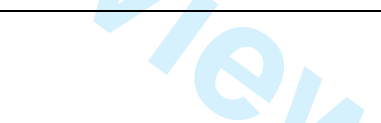 & & \\
\hline Northern Territory & & $\sqrt{ }$ & & & \\
\hline
\end{tabular}




\begin{tabular}{|c|c|c|}
\hline \multicolumn{3}{|c|}{$\begin{array}{c}\text { Table } 2 \\
\text { Australian Domestic violence Order Legislation - Protective Scope (Definitions of Violence and Applicable Relationships) }\end{array}$} \\
\hline$\gamma$ & $\begin{array}{l}\text { Exposure of Children to DOMESTIC } \\
\text { VIOLENCE is included in Definitions }\end{array}$ & Relationships Include Children \\
\hline South Australia & & $\sqrt{ }$ \\
\hline Victoria & $x^{2}$ & $\sqrt{ }$ \\
\hline Western Australia & $\sqrt{20}$ & $\sqrt{ }$ \\
\hline New South Wales & 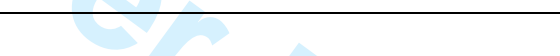 & $\sqrt{ }$ \\
\hline Queensland & $\sqrt{ }$ & $\sqrt{ }$ \\
\hline Tasmania & 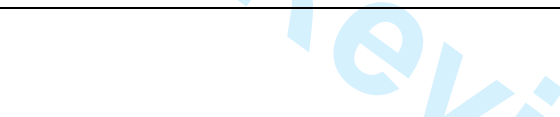 & $\begin{array}{c}\sqrt{ } \\
\text { (But only Spousal Relationships) }\end{array}$ \\
\hline Australian Capital Territory & & $\sqrt{ }$ \\
\hline Northern Territory & & 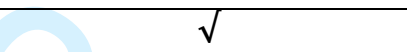 \\
\hline
\end{tabular}


Australian Domestic violence Order Legislation - Procedural Mechanisms, Applications

\begin{tabular}{|c|c|c|c|c|c|c|c|}
\hline & $\begin{array}{l}\text { Named as adjuncts } \\
\text { on adult orders }\end{array}$ & $\begin{array}{l}\text { Can obtain orders in their } \\
\text { own right, application } \\
\text { made on their behalf by a } \\
\text { specified adult, police } \\
\text { officer and/or child } \\
\text { protection worker }\end{array}$ & $\begin{array}{l}\text { Adolescents* can } \\
\text { obtain an order in } \\
\text { their own right } \\
\text { through an } \\
\text { application lodged by } \\
\text { themselves }\end{array}$ & $\begin{array}{l}\text { Police are obliged } \\
\text { to apply for orders }\end{array}$ & $\begin{array}{l}\text { Child Safety } \\
\text { Agencies are } \\
\text { obliged to apply } \\
\text { for orders }\end{array}$ & $\begin{array}{c}\text { Court may } \\
\text { include children } \\
\text { without } \\
\text { application }\end{array}$ & $\begin{array}{l}\text { Court obligated } \\
\text { to include } \\
\text { children without } \\
\text { application }\end{array}$ \\
\hline South Australia & $\sqrt{ }$ & $\sqrt{ }$ & $\sqrt{ }$ & & & & \\
\hline Victoria & $\sqrt{ }$ & $\sqrt{ }$ & $\sqrt{ }$ & & & & \\
\hline Western Australia & & $\sqrt{ }$ & & & & & \\
\hline New South Wales & $\sqrt{ }$ & $\sqrt{ }$ & $x^{2}$ & & & & $\sqrt{ }$ \\
\hline Queensland & $\sqrt{ }$ & $\begin{array}{c}\sqrt{ } \\
\text { (Only in the case of } \\
\text { intimate \& informal care } \\
\text { relationships) }\end{array}$ & $\begin{array}{l}\qquad \sqrt{ } \\
\text { (Only in the case of } \\
\text { intimate \& informal } \\
\text { care relationships) }\end{array}$ & 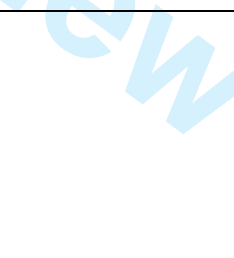 & & $\sqrt{ }$ & \\
\hline Tasmania & $\sqrt{ }$ & $\sqrt{ }$ & $\sqrt{ }$ & & 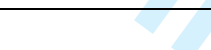 & & \\
\hline $\begin{array}{l}\text { Australian Capital } \\
\text { Territory }\end{array}$ & & $\sqrt{ }$ & $\sqrt{ }$ & & & & \\
\hline Northern Territory & $\sqrt{ }$ & $\sqrt{ }$ & $\sqrt{ }$ & $\sqrt{ }$ & $\sqrt{ }$ & & \\
\hline
\end{tabular}

*Under the age of 18 and depending on jurisdiction anywhere from 14 years year of age 


\begin{tabular}{|c|c|c|c|c|c|}
\hline \multicolumn{6}{|c|}{ Australian Domestic violence Order Legislation - Procedural Mechanisms, Protection of Children in the Court Process } \\
\hline & $\begin{array}{l}\text { Not permitted to give oral } \\
\text { evidence in the courtroom } \\
\text { e.g. evidence can only be } \\
\text { given via recorded } \\
\text { statement, CCTV, in writing } \\
\text { etc }\end{array}$ & $\begin{array}{l}\text { May give oral } \\
\text { evidence in the } \\
\text { courtroom, } \\
\text { protections are } \\
\text { obligatory (e.g. } \\
\text { screens) }\end{array}$ & $\begin{array}{c}\text { May give oral evidence } \\
\text { in the courtroom, } \\
\text { protections are } \\
\text { discretionary }\end{array}$ & $\begin{array}{c}\text { Court may order that } \\
\text { evidence is given via } \\
\text { recorded statement, CCTV, } \\
\text { in writing, video link }\end{array}$ & $\begin{array}{l}\text { Not to be cross } \\
\text { examined by the } \\
\text { Perpetrator }\end{array}$ \\
\hline South Australia & & & $\sqrt{ }$ & $\sqrt{ }$ & $\sqrt{ }$ \\
\hline Victoria & & $\sqrt{ }$ & +3 & $\sqrt{ }$ & $\sqrt{ }$ \\
\hline Western Australia & $\sqrt{ }$ & & +2 & $\sqrt{ }$ & $\sqrt{ }$ \\
\hline New South Wales & & & $\sqrt{ }$ & $\sqrt{ }$ & \\
\hline Queensland & & & $\sqrt{ }$ & $\sqrt{ }$ & $\sqrt{ }$ \\
\hline Tasmania & & & $\sqrt{ }$ & $\sqrt{ }$ & \\
\hline Australian Capital Territory & & & & e & \\
\hline Northern Territory & $\sqrt{ }$ & & & $\sqrt{ }$ & $\sqrt{ }$ \\
\hline
\end{tabular}




\begin{tabular}{|c|c|c|c|c|c|c|}
\hline \multicolumn{7}{|c|}{ Australian Domestic violence Order Legislation - Specified Matters to be Considered by the Court } \\
\hline & $\begin{array}{c}\text { Safety/Protection } \\
\text { of children }\end{array}$ & $\begin{array}{l}\text { Any hardship caused to } \\
\text { children (e.g. education, } \\
\text { accommodation) }\end{array}$ & $\begin{array}{l}\text { Child contact with perpetrator } \\
\text { and the likelihood of this } \\
\text { jeopardising children's safety }\end{array}$ & $\begin{array}{l}\text { Imposition of conditions that } \\
\text { restrict/prohibit contact between } \\
\text { perpetrators and children }\end{array}$ & $\begin{array}{c}\text { Pre-existing Family Court } \\
\text { Orders but child safety } \\
\text { prioritised }\end{array}$ & $\begin{array}{l}\text { Courts directed to use existing } \\
\text { powers under s68R of the } \\
\text { Family Law Act to adjust, } \\
\text { discharge or suspend a Family } \\
\text { Law Act Order }\end{array}$ \\
\hline South Australia & $\sqrt{ }$ & $\sqrt{ }$ & 8 & & & $\sqrt{ }$ \\
\hline Victoria & $\sqrt{ }$ & $\sqrt{ }$ & 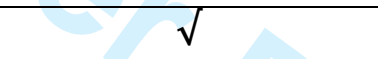 & $\sqrt{ }$ & $\sqrt{ }$ & $\sqrt{ }$ \\
\hline Western Australia & $\sqrt{ }$ & $\sqrt{ }$ & 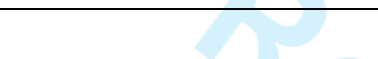 & & $\sqrt{ }$ & $\sqrt{ }$ \\
\hline New South Wales & $\sqrt{ }$ & $\sqrt{ }$ & & A & $\sqrt{ }$ & \\
\hline Queensland & $\sqrt{ }$ & $\sqrt{ }$ & $\sqrt{ }$ & $\sqrt{ }$ & $\sqrt{ }$ & $\sqrt{ }$ \\
\hline Tasmania & $\sqrt{ }$ & & & 1010 & & \\
\hline $\begin{array}{l}\text { Australian Capital } \\
\text { Territory }\end{array}$ & $\sqrt{ }$ & $\sqrt{ }$ & & & & \\
\hline Northern Territory & $\sqrt{ }$ & $\sqrt{ }$ & & & & \\
\hline
\end{tabular}




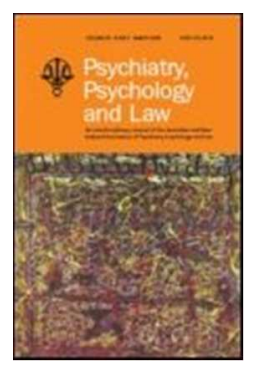

\section{Protecting Australia's children: A cross-jurisdictional review of domestic violence protection order legislation}

\begin{tabular}{|r|l|}
\hline Journal: & Psychiatry, Psychology and Law \\
\hline Manuscript ID: & Draft \\
\hline Manuscript Type: & Original Article \\
\hline Keywords: & $\begin{array}{l}\text { Domestic violence, Child abuse, Child protection, Protection order, Children } \\
\text { affected by domestic violence, Family violence, Intimate Partner Violence }\end{array}$ \\
\hline
\end{tabular}

